\title{
Actualiteit en afscheid
}

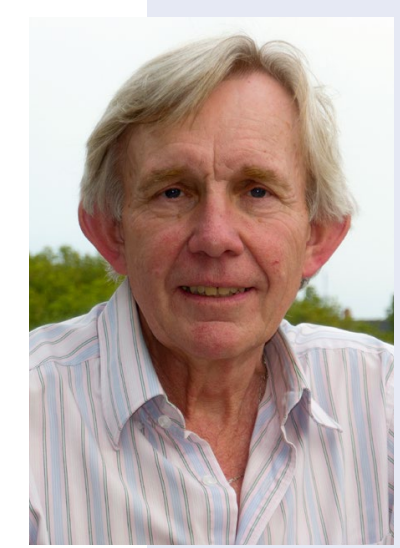

De pandemie lijkt zijn einde te naderen, maar voor bedrijfs- en verzekeringsartsen is het einde nog niet in zicht, juist en vooral omdat voor tienduizenden werkenden COVID-19 nog een lange nasleep heeft. Daarom is het van belang dat we opnieuw - inmiddels voor de derde keer - een special wijden aan COVID-19, die ongeveer de helft van deze editie beslaat. Met uiteraard aandacht voor Long COVID: elke arts krijgt ermee te maken, volgens Hermanns en Pieters.

Een belangrijk onderwerp, dat al eerder aan bod is geweest, is hoe we moeten aankijken tegen een consult op afstand. In het artikel van Sandbrink et al. wordt uitgebreid verslag gedaan van een peiling onder NVAB-leden. Daarbij komt (opnieuw) naar voren dat in een deel van de gevallen een fysiek spreekuur noodzakelijk is om tot een juist oordeel en tot het juiste beleid te kunnen komen. Het lijstje met criteria waarover ik in TBV 8 van vorig jaar sprak kan zo langzamerhand wel worden vastgesteld. Een belangrijke reden voor het fysieke consult is dat daarmee lichamelijk onderzoek mogelijk is. Het lijkt erop dat de noodzaak tot en het nut van lichamelijk onderzoek in de geneeskunde de afgelopen decennia wat naar de achtergrond is verdwenen met de opkomst van steeds meer technische mogelijkheden om (betrouwbare) diagnostiek te bedrijven. Maar bedrijfs- en verzekeringsartsen beschikken zelf meestal niet over dergelijke middelen, terwijl bovendien de fysische diagnostiek regelmatig bij uitstek informatie verschaft over de mogelijkheden tot functioneren van een cliënt. Hoe kijken verzekeringsartsen daar tegenaan in het licht van het streven om tot een zo juist mogelijke vaststelling van de mogelijkheden en beperkingen te komen? Het onderzoek van Van den Berg en Spanjer geeft een duidelijk beeld van de overwegingen van verzekeringsartsen om wel of juist niet lichamelijk onderzoek te (moeten) verrichten. Daarmee wordt in ieder geval duidelijk dat in een belangrijk deel van de gevallen een goede beoordeling op afstand niet mogelijk is.

\section{Nieuw begin}

Dit is het laatste nummer zoals $\mathrm{u}$ dat kent, want we gaan flink veranderen. Het tijdschrift gaat er mooier en overzichtelijker uitzien, met een inhoud zoals u die van ons gewend bent: onderzoek, een grote diversiteit aan praktijkartikelen en als derde pijler: opinie en duiding.

Het nieuwe gezicht brengt ook met zich mee dat vanaf september niet acht maar zes edities per jaar op de mat zullen vallen, waarvan twee dubbelnummers.

Daarmee creëren we ruimte voor het online platform dat eveneens in september de lucht ingaat. Daar vindt u:

- nieuws en actualiteit, waaronder verslagen van symposia en webinars;

- blogs en opinie;

- (wetenschappelijk) onderzoek, ook kleinschalig onderzoek zoals afstudeerwerk van aios;

- toegang tot vakinhoudelijke en wetenschappelijke informatie, aangeboden per thema;

- ruimte voor interactie.

Onder andere om $\mathrm{u}$ op al dit moois te attenderen zal tevens een LinkedIn-pagina worden gestart.

Een speciale webredactie, die onderdeel is van de TBV-redactie, zal deze media gaan beheren en van de nodige inhoud voorzien.

The sky is the limit. Met deze boodschap lijkt de telewerker op de omslagfoto het nieuwe TBV alvast te verwelkomen. 